This is the version of the article accepted for publication in China Quarterly published by Cambridge University Press:

DOI: https://doi.org/10.1017/S0305741019000018

Accepted version downloaded from SOAS Research Online: http://eprints.soas.ac.uk/25921

\title{
China's Asset Management Companies as State Spatial-Temporal Strategy
}

\author{
Sarah $\mathrm{Ho}^{1}$ \\ Thomas Marois ${ }^{2}$
}

\begin{abstract}
Chinese authorities created four new asset management companies (AMCs) in 1999, which have since undergone profound transformations that have been influential in China's contemporary integration into the world market. Conventional interpretations see these powerful AMCs in largely technical and asocial terms. By contrast, we employ a critical geographical analytical framework to understand the transformation of the AMCs as an expression of state spatial-temporal strategy, which involved attempts to create conditions of political economic stability now by displacing the conditions of financial instability and crisis into the future. This strategy does not come without unintended and destabilizing consequences, nor is it without class-based social and political implications.
\end{abstract}

中国政府在 1999 年设立了四家资产管理公司, 它们经历了重大变化, 并对中国近年融入国际 市场的过程影响深重。对这些庞大的资产管理公司的解读, 一般都从技术性及非社会性的层面 出发。相比之下, 我们利用批判性的地理分析框架, 把资产管理公司经历的变革理解为国家时 空管理策略的表现。该策略企图把现存的金融不稳定及危机推延至未来, 以制造现时的政治经 济稳定。这策略的执行不仅藏有未遇见和不稳定的后果, 亦为社会和政治上的阶级斗争带来启 示。

\section{Keywords}

China, Finance, Asset Management Company, Political Economy, Spatial Strategy, Development, Transformation, Institutions

中国，金融，资产管理公司，政治经济，空间策略，发展，转型，机构

Sarah Ho is a qualified solicitor in Hong Kong and has completed her MSc Development Studies at SOAS University of London.

Thomas Marois is a Senior Lecturer of Development Studies, SOAS University of London. He is author of the 2012 book, States, Banks and Crisis: Emerging Finance Capitalism in Mexico and Turkey (Edward Elgar). 
The financial transformations experienced by the big emerging capitalisms like Brazil, Mexico, Turkey, India, South Africa, and China have been subject to increased study in their own right. A notable conclusion has been the variegated nature of each society's integration into financial world markets. The focus therein has been on structural transformation. Rather less studied are the roles of particular financial institutions, that is, on the institutions constitutive of financial structures.

This is our study's empirical point of departure in the case of China. We seek to understand the emergence and transformation of China's four large asset management companies (AMCs) vis-à-vis the society's grander financial evolution. Each AMC was initially intended as a temporary institution destined to handle the 'Big Four' state-owned banks' mounting non-performing loans (NPLs): Cinda, for the China Construction Bank; Huarong, for the Industrial and Commercial Bank of China; Great Wall, for the Agricultural Bank of China; and Orient, for the Bank of China. Yet as the AMCs enabled China's global financial integration so too did the AMCs scale up their operations, thereby assuming a lasting significance.

Theoretically we draw on a critical geographical framework, and in particular on ideas of state spatial-temporal strategy (SSTS). Through this analytical lens, we argue that the AMCs represent an institutionalized form of SSTS, wherein their malleable social content reflects political and class-based strategies. Over time we see that the AMCs have become constitutive of China's financial transformation, but not necessarily as originally anticipated. This interpretation challenges mainstream accounts that often reduce China's AMCs to technical problem-solvers, while engaging with critical geographical understandings of how financial crises are displaced.

Three premises substantiate our argument. First, the SSTS analytical lens helps to uncover insights otherwise obscured by mainstream approaches. Second, China's AMCs emerged as one of several possible state strategies meant to displace and defer escalating financial risks. Third, the newly-formed AMCs subsequently underwent three phases of transformation in ways first meant to preserve but then to intensify China's financial transformation. These are followed by a brief conclusion.

\section{Interpreting AMCs as State Spatial-Temporal Strategy}

Employing a SSTS framework reveals insights into China's AMCs otherwise hidden by mainstream approaches. Neoclassical studies, for example, typically frame AMCs in socially-neutral technical language as problem-solving institutions, wherein the largest problem has been the post-1980s spike in systemic banking crises and financial instability. ${ }^{3}$ Notwithstanding other state-led rescue and recovery strategies, AMCs are posed as an effective policy response to rapid increases in non-performing loans (NPLs) and subsequent bank insolvencies. ${ }^{4}$ Understood thusly AMCs just absorb the failed banks' NPLs ('toxic' assets) so these same banks can recover and resume normal operations. ${ }^{5}$ While in practice market interventionist, in discourse the AMC strategy is framed as market friendly: competitive banking can recommence while the prospects of economic recovery are enhanced. ${ }^{6} \mathrm{~A}$ win-win scenario.

The Bank for International Settlement (BIS) dubs this the "good bank - bad bank" approach, wherein AMCs are described as "asset separation" tools. ${ }^{7} \mathrm{~A}$ new AMC materializes as the "bad bank" that institutionally firewalls the failed banks' toxic assets. ${ }^{8}$ The recapitalized cum rescued banks are rebranded as "good banks" able to refocus on core business and financial sustainability, and therefore be attractive to investors. ${ }^{9}$ The AMC technical fix has emerged as a viable mainstream alternative to the otherwise massive and immediate liquidation of NPLs amidst crisis. Conceived of in apolitical and problem-solving terms, 
however, the approach obscures underlying socio-political and often contested relationships of power and class.

A SSTS framework facilitates an alternative reading. Bob Jessop defines state spatial strategies as follows: ${ }^{10}$

These strategies refer to the historically specific practices through which state (and imperial) institutions and state managers (and the social forces they represent) seek to reorder territories, places, scales, and networks to secure the reproduction of the state in its narrow sense, to reconfigure the sociospatial dimensions of the state in its integral sense, and to promote specific accumulation strategies, state projects, hegemonic visions, or other social imaginaries and projects.

As the "spatialities" of state are comprised of institutions and regulatory capacities tied to the "territorialization of political power", ${ }^{11}$ it is useful to fill in such abstractions via concrete institutions like the AMCs. In this way state financial institutions, like banks or AMCs, offer a vantage point into the dynamics of the wider state formation. ${ }^{12}$ Further to this, we draw on Jessop's notion of 'institutional fix' (and temporal horizons), which he specifies as: ${ }^{13}$

“... a complementary set of institutions that, via institutional design, imitation, imposition, or chance evolution offer (within given parametric limits) a temporary, partial, and relatively stable solution to the coordination problems involved in securing economic, political, or social order. Nonetheless, it is not purely technical and, rather than providing a post hoc solution to pre-given coordination problems, it is partly constitutive of this order."

These analytical concepts have a long theoretical lineage within the fields of historical materialism and critical geography, the latter building on the foundational works of Henri Lefebvre and David Harvey. An advantage of this framework is that institutionalized responses to crisis, like AMCs, are not conceived of as the seamless, unmediated unrolling of structural forces, despite structures being analytically significant. Rather, social forces (composed of individual and collective agents) pursue socio-political and spatial strategies, thus producing 'space', to help realize their interests and to manage the contradictions and crises that recurrently arise in contemporary capitalism. While such strategies are predominantly undertaken at the national level, they are nonetheless integrally linked to global and sub-national scales and processes. ${ }^{14}$

Temporally, state spatial strategies aim to 'fix' instability by shifting the financial costs and risks of ensuring current economic stability into the future. According to Jessop, should a fix succeed, so to speak, then "current zones of stability imply future zones of instability". ${ }^{15}$ For Jessop, crises are never really resolved, just displaced: fixes contain crises and contradictions now, but only to have them reappear down the road and in need of new fixes. ${ }^{16}$

On this point we depart from Jessop and others who see fixes as recurrently displacing but never resolving crises. Often in Marxian accounts of transformation and change, crisis is understood as "an essential and ineradicable feature" of capitalism that exposes its inherent contradictions. ${ }^{17}$ Fair enough. But if an analytical position posits that crises are never resolved, only displaced, this implies that capitalism is always in crisis. This empties out the concept of crisis. ${ }^{18}$

By contrast, we see specific crises as resolvable, depending on specific circumstances and class relations. According to Thomas Marois: "the ways in which minor and major crises are resolved, or not, is historically contingent on domestic social affairs, state institutional capacity, relative balance of power between capital and labor, and global pressures". ${ }^{19}$ 
Contemporary financial capitalism is dependent on state capacity to manage financial crises by pushing the costs into society: states socialize the financial costs and risks, thus resolving them ${ }^{20}$ (and here we begin to see the logic of Chinese state authorities turn to the AMCs amidst crisis). This resolution process by no means precludes new crises emerging. But neither should we overlook the political agency deployed, the flexibility of prevailing social logics, and class consequences suffered at moments of crisis resolution.

Finally, we expand on Jessop's approach by employing a Marxian-inspired social content approach to the AMCs. This approach is distinguished by its historical-structural and agentled understanding of how institutions in capitalism are formed and reformed. Both the structural imperatives of competitive capitalism and the agency of individual and collective actors matter in ways that cannot be theoretically predetermined (hence, the very opposite of neoclassical economics). This understanding draws on two aspects of Rudolf Hilferding's work (1981[1910]). First, through his focus on the historical social relations of power and class, finance capital is understood as a social and political force. Second, he highlights that progressive change is possible by social forces taking over and mobilizing banks. Building on these insights, our approach to financial institutions challenges conceptions that see banks as unmediated institutional derivatives of market processes or, for that matter, class relations. In short, not as a priori black boxes. Instead, a social content approach sees financial institutions like AMCs as "institutionalized social relations that reflect historically specific relations of power and reproduction between the banks, other firms, the state, and labor in general". ${ }^{21}$ The remainder of the paper combines the social content and SSTS approaches.

\section{The Emergence of China's Asset Management Companies}

The emergence of China's AMCs is closely tied to China's contemporary financial reforms, which began in the 1980s and involved moving towards a more market-oriented and commercial banking model. State authorities began by designating The People's Bank of China (PBOC), formerly the only institution handling both commercial banking and macroeconomic financial policy, as the Central Bank in 1983. ${ }^{22}$ Authorities then created four state-owned specialized commercial banks from the PBOC - the Bank of China (BOC), the Agricultural Bank of China (ABC), the China Construction Bank (CCB), and the Industrial and Commercial Bank of China (ICBC) - to handle foreign exchange, agricultural finance, infrastructure investment, and credit and savings businesses respectively.

[Insert Table 1 about here]

Chinese authorities further experimented with market-oriented reforms in the 1990s. One move in 1995 included turning the 'Big Four' banks into commercial banks to distinguish them from the three policy (development) banks created two years earlier. ${ }^{23}$ The government also began withdrawing budgetary support for state-owned enterprises (SOEs), replacing them with bank loans. The Big Four banks became the main source of financing for China's SOEs. ${ }^{24}$ This occurred as China began showing signs of structural economic change: between 1980 and 1995 domestic debt increased from 53 to 87 per cent of GDP; foreign direct investment exploded from $\$ 400$ million (about 0.2 per cent of GDP) to $\$ 36$ billion (4.9 per cent of GDP); and exports tripled from 6 to 18 per cent of GDP (Table 1).

Corresponding lending to SOEs absorbed from 20 to 60 per cent of the four banks' assets, by various estimates. ${ }^{25}$ While this allowed state authorities to finance market reform, maintain SOE employment levels, and prioritize infrastructure, it also meant a substantial accumulation of public sector debts. ${ }^{26}$ In the wake of the 1997-98 East Asian Crisis some 30 to 50 per cent of outstanding loans were non-performing, threatening to drag the Chinese economy into crisis unless action was taken. ${ }^{27}$ Official data shows this falling to just over 13 
per cent by 2004 (Graph 1), which is still seen as extraordinarily high by most commentators.

Possible strategic responses to the banks' NPLs had already been discussed during an August 1994 Beijing conference, titled "The Next Step of China's Economic Reform". ${ }^{28}$ Zhou Xiaochuan 周小川 [then vice-chair of the BOC (and Governor of the PBOC since 2002)] and the State Economic and Trade Commission [(SETC) the top agency within the Chinese central government leading economic reforms in the 1990s] led the proceedings. The proposals focused on bank recapitalization and reducing SOE indebtedness, but without straining the national budget. Recommendations included converting the NPLs into SOE share capital to be held by the banks or the state (that is, debt-to-equity swaps). ${ }^{29}$ No immediate action was taken, however, as China was yet to confront real financial crisis, the likes of which Mexico and Turkey were then facing.

The 1997-98 East Asian financial crisis, while largely skirting China, changed perceptions. This coincided with the transition of premiership to Zhu Rongji 朱F基 in 1998, an adamant reformer, who quickly moved to consolidate power over the financial sector. This included a one-off injection of RMB270 billion (US\$35 billion) into the banks to reach the Basel recommended eight per cent capital adequacy ratio. Still, the outstanding NPLs remained significant. Zhu Rongji called on fellow reformer Zhou Xiaochuan to come up with a solution - one that drew from the 1994 Beijing Conference and from which the AMC 'fix' would ultimately emerge. ${ }^{30}$

Three points stand out regarding the intended design of the AMCs. First, creating a new AMC fix was not an obvious response. Instead their potential linked to the political rise of Premier Zhu Rongji and an associated ideological shift. China's debt problems were to be addressed through a mix of fiscal spending and market-oriented measures. ${ }^{31}$ This marked the AMCs' institutional content with a political and economic stamp of China's transformation. Second, state authorities intended the AMCs to have a short life. Although not formally written into law, the official media widely reported on their ten-year lifecycle, which was affirmed by Zhou Xiaochuan ${ }^{32}$. The AMC bonds and debt-to-equity swaps, too, carried 10-year maturities. ${ }^{33}$ Third, the AMCs materialized with no clear blueprint for their future development or funding requirements. ${ }^{34}$ Official regulations only stated that the Ministry of Finance (MOF) must prepare the final bill when the AMCs close but nothing bound the MOF to footing the bill.

In 1999 China's State Council finally approved the formation of four AMCs, each tethered to a Big Four state bank. The State Council intended the AMCs "[t]o prevent and reduce financial risks, provide a lawful disposal of state-owned commercial banks' distressed assets, and strengthen the assessment of state-owned commercial banks' operation situations". ${ }^{35}$ Their primary mission was nevertheless the takeover, management, and handling of distressed assets extracted from the Big Four banks while their main operation targets involved the "maximization of asset preservation" and "loss reduction". ${ }^{36}$ Profitability was not yet a prime directive. The MOF endowed each AMC with initial equity totaling RMB10 billion. ${ }^{37}$ This capital stake was evidently inadequate as the AMCs were expected to take over NPLs worth some RMB1.3 trillion. ${ }^{38}$ The additional funds would come from PBOC loans and AMC bonds.

The emergence of China's AMCs, then, is shaped by their unique capacity as financial institutions to displace financial risks gone bad (that is, the banks' NPLs). This occurred spatially within the state apparatus, as the AMCs drew in, centralized, and concentrated otherwise geographically and institutionally diverse financial risks. It also occurred temporally, as the AMCs shifted current state financial risks into the future. These strategies worked together to stave off immediate financial crisis. 


\section{The Transformation of China's AMCs}

From their establishment in 1999 to the listing of two AMCs in 2013 and 2015, China's AMCs transformed in ways reflective of shifting state spatial-temporal strategy (SSTS). Three phases help to frame these changes: 1999 to 2003; 2003 to 2009; and 2009 on. Far from being mere technical agents of debt-resolution, the AMCs evolved to facilitate China's integration into financial world markets.

\section{A. 1999 to 2003: Displacing NPLs}

The first phase of China's AMC operations corresponded to their intended strategic purpose: the acquisition and financing of the state banks' NPLs in order to preserve financial stability and enable market-oriented reforms. By 2000, the Big Four banks had transferred RMB1.4 trillion (US\$170 billion) in NPLs to the four AMCs, which the AMCs acquired at full face value.$^{39}$ Not only was there no 'haircut' or reduction on the value of the loans absorbed, but the rate of interest paid was decent (the Cinda-CCB bond earned 2.25 per cent, see CCB 2010). Up to 60 per cent of the PBOC's NPL claims were shifted to the AMCs ${ }^{40}$. This intrastate spatial repositioning of debt enabled the banks' bad debts to be displaced into the future. The Big Four's new lending need not be weighed down by having to monitor the repayment of their old bad loans as past NPLs became reclassified as receivables. The scheme thus functioned as an indirect injection of capital by the state to facilitate the authorities' strategy of market reform.

It is worth noting that the Chinese authorities created "constructive ambiguity" around the official backing of the debts. ${ }^{41}$ Specifically, the AMC bonds did not carry an explicit state backing. Implicitly, however, investors understood that the bonds had implicit state backing. The AMC bonds consequently enjoyed a sovereign-like zero risk weight, which helped to improve the capital base of the recipient state banks. ${ }^{42}$ Still, by not affirming an official guarantee, the Chinese government avoided being economically burdened by the bonds in its public balance sheet in the here and now. State authorities evaded the issue of responsibility for any ultimate losses - be it the banks, the AMCs, the MOF, or the PBOC. As for the rescued banks, unhinging them from their NPL noose sent them on a path of skyrocketing growth and capital accumulation. Between 2005 and 2010, each of the Big Four banks were listed on the Hong Kong Stock Exchange. This as domestic credits ballooned from less than 90 per cent of GDP in the mid-1990s to over 140 per cent by 2010 (Table 1).

State authorities further intended the AMCs to undertake debt-to-equity swaps with Chinese SOEs. The SETC, part of the power base of Premier Zhu, designed and led the scheme. ${ }^{43}$ First, the SETC identified appropriate SOEs. Selection was based on whether an indebted SOE was established during key eras of reform (and hence heavily indebted with policy loans) and/or whether the SOE fell into the group of 521 key industrial enterprises. ${ }^{44}$ The SETC list was then passed onto the AMCs for independent assessment and vetting. As the AMCs rejected a mere $3 \frac{1}{2}$ per cent of the recommended SOEs (for reasons unknown), it is likely that the AMCs had little autonomy to modify the list - itself likely pegged to a larger state strategy. The AMCs were then responsible for formulating debt conversion plans and agreements for each selected SOE, which the SETC reviewed for approval. ${ }^{45}$ In general, China's indebted SOEs enthusiastically greeted the plan, flocking to be included. ${ }^{46}$ In total, district level governments had nominated 3875 SOEs. Of these, the SETC selected 601 for assessment by the AMCs, with 580 being chosen for debt conversion. ${ }^{47}$ The total loans converted amounted to RMB405 billion, representing 30 per cent of the policy-based NPLs transferred to the AMCs. ${ }^{48}$ As with the Big Four banks, so too with the SOEs. The AMCs managed the intra-state spatial displacement of the SOE NPLs in order to shift these financial risks into the future. The SOEs could now too undertake market-oriented reforms. 
By the end of 2002, the four AMCs had disposed of a total of RMB301.4 billion bad debts (excluding debt-to-equity conversion) and recovered RMB101.3 billion, which include RMB67.5 billion in cash. ${ }^{49}$

By 'fixing' selected state bank and SOE debt problems, the AMCs internalized the economic state strategies of the moment while simultaneously enabling the realization of state marketoriented strategy. This gave shape to the AMCs' social content, initially derived from the political intentions of Premier Zhu Rongji. The realization of the AMC strategy thus helped to cement his reform agenda. According to one high-level interviewee, "Zhu values the power to distribute financial resources through loans and stock-listings, and he has used the power as chips in the political game". ${ }^{0}$ The SETC mobilized the AMCs to help filter and handpick the industries and enterprises that were close to Zhu Rongji's strategic outlook, thus influencing and shaping China's transformation.

The AMC strategy did not always work as anticipated. A 2003 survey looked at 24 randomly selected SOEs in northwestern China that participated in the debt-to-equity conversion program. ${ }^{51}$ Among these eleven were profit-making before the conversion. Nine of them remained profitable by the end of 2003 , with six recording higher and three lower profitability. Of the 13 pre-conversion loss-makers, only one became profitable. Twelve others still recorded losses: eight reduced losses but four incurred heavier ones. While the AMCs could ease the financial burden for some and allow others to reform, the conditions of the industries, markets, and internal governance of the companies also mattered. Shift bad debts in time and space, yes, but perform miracles, no.

Yet the AMCs were hardly a strategy confined to the national scale, coinciding as they did with China's World Trade Organization (WTO) accession in 2001. The take-off of foreign direct investment marks this internationalization: $\$ 42$ billion in 2000 soon paled compared to the $\$ 104$ billion reached in 2005 which again paled compared to the $\$ 244$ billion reached five years on (Table 1). Among other reforms, WTO accession also involved leveraging foreign competition to weaken domestic resistance to market reform. ${ }^{52}$ For example, to be WTO compliant the listing of China's SOEs and banks meant adopting new corporate governance standards in the search for new, preferably international, investors as a way to deliver stronger balance sheets. ${ }^{53}$ And, of course, to draw in capital from abroad. If a SOE secured AMC restructuring support then international investors often saw greater value in the SOE, portending its potential global success and higher returns on investments. ${ }^{54}$

At this point the benefits of the AMCs as SSTS appeared substantial, if not bullet proof, but the indefinite time period of the NPL resolution schema would generate unanticipated problems for state authorities.

\section{B. 2003 to 2009: Transforming the AMCs}

The AMCs were entering their fourth year, amidst a global economic upturn, but the State Council was becoming concerned with their future. ${ }^{55}$ Two major factors fed its concern. First, AMC progress in disposing of NPLs appeared to be stalling. While overall disposal volumes increased by about RMB200 billion between 2004 and 2006, the cash recovery rate was proving largely stagnant (Table 2). On average the recovery rate had reached about 22 per cent (with big differences among the AMCs), but this covered less than half of the AMCs' interest costs (Table 2). ${ }^{56}$ State authorities worried that the AMCs would be unable to meet ongoing interest obligations or to repay the bonds as they matured in $2009 .{ }^{57}$ Put otherwise, the intra-state strategy of concentrating bad financial risks in the AMCs to push them into the future was confronting the fact that this spatial-temporal displacement had not meant their material resolution (or infinite displacement). Real financial commitments (and possible losses) remained, and these could trigger instability. Should this occur, the knock-on effect would be significant stress on the Big Four banks holding the AMC bonds. This risked wider market reform aspirations, hence generating concern within the State Council. 
[Insert Table 2 about here]

Second, WTO entry meant Chinese state authorities were obliged to open up the country's borders by December 2006, notably to foreign capital in its banking sector. China's step into the financial world market now had a date. To ensure that the Chinese state banks could compete, authorities targeted the end of 2006 for completing banking reform and disposal of the NPLs. ${ }^{58}$ Yet after the first tranche of RMB1.4 trillion in NPLs in 1999 to 2000, the Big Four banks still had RMB2.2 trillion in bad loans. ${ }^{59}$ This, together with the MOF's resurgent victory in its power struggle with the PBOC, prompted a shift in strategic direction for the AMCs.

By early 2004 the MOF had moved to assume leadership over China's financial transformation, spearheading commercialization (meaning a greater orientation towards competition and profit maximization). This signaled a qualitative shift in the strategic orientation of the AMCs as temporary institutional fixes for NPLs. ${ }^{60}$ In February the MOF issued a "Request for Advice on Questions Concerning Reform and Development of the AMCs" to the State Council. ${ }^{61}$ In the Request, the MOF proposed using more marketoriented measures, like Cash Recovery Ratio and Expense Ratio, to evaluate AMC performance. Upon reaching set targets, an AMC could switch to a commercial operational orientation. The State Council approved the Request, marking a new institutional shift in the AMCs' social content.

[Insert Graph 1 about here]

The institutional change brought operational changes. To meet commercial targets, the AMCs could make discretionary asset investments, undertake commercial bidding for toxic assets, and establish platform companies (for example, financial leasing, trusts, and so on) for the purposes of restructuring and disposal of distressed assets. ${ }^{62}$ By the end of 2006, all four AMCs had met their targets. This allowed them to complete their transformation into fullfledged, market-oriented financial institutions. ${ }^{63}$ What were once politically intended as temporary fixes for economic instability had now, in the context of China's ambitions to enter financial world markets, transformed to embody a new strategic direction. In doing so, the AMCs would project themselves as powerful agents of Chinese financial engineering.

The MOF's strategy to transform the AMCs into a new tool of financial and economic power did not come without complications. For one, the MOF's move to extend the life and scope of the AMCs involved politically-loaded fiscal calculations. The foundational SSTS to concentrate NPLs in the AMCs in order to displace them in the future was now coming of age. The intended closure of the AMCs within a decade, as originally envisaged by the PBOC, meant that the AMCs would have to start resolving the original losses in the here and now - but with the MOF footing the bill. ${ }^{64}$ That is, the losses would have to become fixed in time and space.

Realizing presently the past NPLs concentrated in the AMCs was politically unacceptable and likely economically destabilizing. So when the MOF regained ascendancy over the PBOC authorities opted to defer the debt problem. ${ }^{65}$ In short, the MOF kicked the original 'debt can' further down the road. But to do so the MOF needed a new SSTS. This entailed issuing notices to the banks and the AMCs in 2004 and 2005 confirming that the MOF would provide financial support for the bonds' interest and principal payments. That is, the MOF would absorb part of the AMCs' losses by again spatially displacing but now deconcentrating financial responsibility across the state apparatus. In temporal terms, when the AMC bonds reached maturity in September 2009, the MOF would extend their terms by another 10 to 20 years. ${ }^{66}$ It would use China's financial institutions to literally make time available. ${ }^{67}$ Debt displacement as SSTS had worked once, why not again? 
The now more mature AMCs enacted the MOF strategy, justifying their renewed lease on life. Their accumulated capital and financial expertise signaled the rise of the AMCs as an influential socio-political force. Commentators argued that there was good reason for the AMCs to remain alive, especially as they may be useful for handling any future distressed assets. ${ }^{68}$ The four AMCs themselves lobbied hard in this direction, as evidenced by their frequent conference speeches and publications. ${ }^{69}$ This alone, though, would have only kept the AMCs on life support. More materially, the AMC spatial-temporal fix had contributed to making domestic markets and market reform, facilitating Chinese state authorities' capacity to bring about world market integration.

A significant factor, then, in the MOF's decision to grant the AMCs new investment powers involved the changing reproductive logic of the Chinese state in governing a more marketoriented economy and capital accumulation. ${ }^{70}$ The influx of foreign investment, overseas listings of SOEs, and China's internationalization meant the government could no longer control the economy as before. Indeed, this is reflected in the massive buildup of total official reserves (a form of state self-insurance against capital outflows) from $\$ 172$ billion in 2000 to just under $\$ 3$ trillion by 2010 (Table 1). Guo Shuqing 郭树清, past Chair of the CCB and current Communist Party Secretary and Deputy Governor of the PBOC and Chair of the China Banking and Insurance Regulatory Commission, captured this transformative process when writing on the challenges before the Chinese economy: ${ }^{71}$

The qualitative changes ... in economic operations ... indicated that, in terms of managing the economy, we could no longer rely solely on administrative measures, but instead had to shift to indirect measures to influence economic performance. It became impossible not to change the entire formulation and operating mode of macroeconomic policies in China.

For example, with the stakes they already held in key SOEs through the debt-to-equity swaps, the AMCs were able to take up the role of institutional investor in strategic industries. ${ }^{72}$ This introduced a new form of ownership and control in China, wherein state authorities relinquished direct ownership while retaining indirect control through other public institutions, like the AMCs. ${ }^{73}$

In transforming themselves and their spatial-temporal orientation during this phase, the AMCs facilitated changes within China's internationalizing political economy. AMC transformation, however, was not yet complete.

\section{2009 Onwards: Consolidating Commercialization}

The onset of the global financial crisis in 2008 sparked a shift in Chinese economic development. China had limited exposure to the US sub-prime mortgages and was therefore less impacted than the US and Europe. The global crisis, nonetheless, inflicted a heavy blow to global demand. China, whose strategy of development over the previous 20 to 30 years had turned increasingly to exports and foreign direct investment (Table 1), recorded severe trade shocks. Its GDP growth rate dropped from around 10 per cent per year to 6.8 per cent in the fourth quarter of 2008 , before rebounding. The Chinese government responded in November with an unprecedented RMB4 trillion (US $\$ 586$ billion) stimulus package. ${ }^{74}$ Given China's significance, foreign economists also recognized that bolstering its economy was key to prospects of global recovery.

Government- and bank-led investments designed to boost domestic demand defined China's stimulus. ${ }^{75}$ To this end, authorities instructed the state-owned banks to more than double their lending targets from RMB4.7 trillion in 2008 to RMB10 trillion in 2009, especially via infrastructure, new environmental programs, and consumer spending (notably 
mortgages), and to reduce restrictions on corporate bond issuances and financial products. ${ }^{76}$ These helped to deliver a 9.4 per cent growth rate in 2009 and 10.6 in 2010 (Table 1). Still, domestic demand was slow to catch up. ${ }^{77}$

There would be unintended consequences to the stimulus. Pumping billions into the economy enabled investors with excess liquidity to turn to the stock and real estate markets, supercharging speculative activities. ${ }^{78}$ This gave rise to new problems of property speculation and mounting bad debts. ${ }^{79}$ That is, Chinese authorities' attempts to displace the 2008-09 financial crisis by mobilizing massive amounts of credit in the present gave rise to present and future conditions of crisis. ${ }^{80}$ This, in turn, would demand a new SSTS, which would again bring the AMCs to the fore of Chinese political economy.

Resurrecting the specter of past crisis resolution strategies, commentators and AMC senior management highlighted AMC successes in handling the previous batch of NPLs and in restoring China's banks and SOEs to economic health. ${ }^{81}$ The AMCs were being discursively framed, and increasingly seen, as "a stabilizing factor" in China's unstable economy. ${ }^{82}$ In Premier Wen's 2010 Annual Working Report, he specifically highlighted the need to build a sound financial system to withstand the shocks of the global financial crisis; this included the continued transformation and commercialization of the AMCs. ${ }^{83}$

The AMCs had by this time stretched their operations into a comprehensive range of financial services - which included fund management, securities, insurance, futures, private equity, real estate, and trusts - in part by taking over ownership and control of insolvent financial institutions that held the relevant licenses. ${ }^{84}$ What the AMCs now needed was more capital to absorb the emerging NPLs. ${ }^{85}$ For this, the AMCs had to project their capital-raising capacities beyond China and into world financial markets. For that, the government strategized to publicly list the AMCs. Whereas before authorities were willing to displace bad debts domestically and within the state in order to push them into the future, now SSTS would assume an outward-orientation. This meant deeper commercialization.

At the time, Cinda was the strongest performing AMC (its cash recovery ration of over 30 per cent was miles ahead of the others, Table 2), and so was chosen to pioneer the listing process. ${ }^{86}$ To do so, the government converted Cinda into a joint-stock company with the MOF as the sole shareholder in 2010, the usual first step for a Chinese SOE to get listed. ${ }^{87}$ The next task was to deal with the original bonds issued by the AMCs for the Big Four banks' NPLs. That is, authorities now had to explicitly resolve the first displacement of bad debts.

In a 2010 CCB announcement (confirmed later by Cinda), the MOF agreed to continue providing interest support on the CCB's Cinda bonds, with a book value of RMB247 billion. ${ }^{88}$ The principal, however, was to be repaid by a MOF-owned but jointly-managed Cinda-MOF Fund. While displacing the bad debts once more, the MOF signaled a concrete amortization period by projecting them to last until September 2019. But where would the money to fund the Fund come from? From enterprise income tax paid by the CCB and 'other appropriations' made by the MOF .89

The implications of this new state strategy are significant. Through MOF payments and via the CCB-paid enterprise income taxes, authorities could finally 'fix' or resolve the original NPL debt problem. The resolution is as political as it is financial, and it involves explicit socialization of the debts through the state apparatus. Socialization is here understood as a constitutive state strategy of neoliberal financial transformation whereby "state authorities diffuse the worst and most costly financial risks onto workers in society through the state apparatus". ${ }^{90}$ This is possible because state authorities collect geographically diffuse tax payments within their territory, from individuals and enterprises to greater and lesser degrees, concentrating the payments in the public purse to be later dispersed. Governments 
can borrow against this because they collect taxes. Taxation links public expenditure to the general public and, as such, public expenditure decisions are politically loaded. As per the AMCs, for authorities to explicitly resolve the initial bonds meant firmly committing public resources: namely, the taxes paid by the CCB and other MOF 'appropriations'. These public resources would enable the further market-oriented commercialization of their social content. And this commercialization was being financed via socialization, which enabled the AMCs (and by extension state authorities) to respond to the current crisis.

The socialization of bad debts is distinctly class-based insofar as public sectors resources and taxation funds their resolution. As one BIS economist understands it (albeit not in class terms) vis-à-vis China's system-wide resolution of China's debts (not just the AMCs): ${ }^{91}$

Thus, taxpayers, shareholders and bank customers have all shared the restructuring bill. The MoF and PBC together have taken care of 85 per cent of the bill, with the rest of the tab being picked up by bank shareholders, investors and customers. Therefore, the consolidated public sector (ultimately the taxpayers) is bearing the lion's share of the overall bill.

Upon clearing the way for settling cum socializing the bond obligations, Cinda AMC opened to strategic investors in April 2012. These included the National Social Security Fund of China, UBS, CITIC, and Standard Chartered, who together held 16.54 per cent of Cinda before its listing ${ }^{92}$. Cinda was then floated on the Hong Kong Stock Exchange in December 2013. It raised US $\$ 2.5$ billion and was crowned the largest IPO of the year. ${ }^{93}$ Cinda's commercial outputs skyrocketed (Table 3). Total assets have more than quadrupled as net profits doubled from 2012 to 2016. Cinda's ROAA and ROAE measures have slipped since 2012, given current debt problems, but current levels (1.82 \& 14.12 respectively, Table 3 ) still locate it among the top financial performers globally.

[Table 3 about here]

The Huarong AMC was listed in October 2015 raising $\$ 2.3$ billion, and its commercialization has delivered even more dramatic commercial results (Table 3). Total assets have ballooned four and a half fold with net profits more than tripling. Huarong's returns have remained steady since 2012. At 18.4 per cent ROAE and 2.0 per cent ROAA, it steadily outperforms Cinda.

As for the two other AMCs, Great Wall and Orient, the former completed restructuring into a joint-stock company in December 2016 while the latter is in the process of doing so, both paving the way for an eventual listing - which as of early 2018 is officially unconfirmed. ${ }^{94}$ Further commercial changes are likely as the AMCs explore rebranding themselves as investment banks with ambitions of competing globally with the likes of Goldman Sachs and JP Morgan. ${ }^{95}$ As financial instability continues to loom across China's economic horizon, ${ }^{96}$ the place of the AMCs in China's state financial apparatus appears assured.

In this phase we see how SSTS can manifest differently. In the context of global financial instability and commercialisation pressures, past implicit official guarantees needed to be replaced by explicit official guarantees and payment schemes that spatially dispersed the NPLs risks onto society through the state apparatus in order to fix a date of resolution. Socializing the past bad debts opened the door to drawing in new private investors and commercialization, with resulting dividends being paid out. This further altered the original intended social content of the AMCs. The Chinese AMCs continue to feed on bad debts, as China sells off further tranches of NPLs. Now, however, the AMCs and their investors are watching closely. This is not just to see how they might contribute to managing financial instability within China's borders. Investors are also wondering how they might be able to 
exercise their spatial-temporal toolkit to generate lucrative new sources of capital accumulation.

\section{Conclusion: The Significance of China's AMCs}

Viewed through a lens of state spatial-temporal strategy (SSTS) China's AMCs become much more than just technical problem solvers. Rather they reveal themselves as complex and malleable institutionalizations of political and economic struggles, which themselves have class-based determinations. While first conceived of as temporary and implicit fixes for China's NPL problems of the 1990s, market-oriented restructuring during the 2000s meant the AMCs became targets for and agents of capital accumulation. The lure of foreign investment influenced changes in the AMCs. State authorities modified its approach to SSTS in the AMCs to explicitly resolve their past NPLs dealings by socializing them over a fixed term and across society. This 'fix' provided private investors with the rock-solid certainty they needed to buy into the commercializable AMCs. This enabled the listed AMCs to project their debt management dealings beyond the confines of China's borders and into financial world markets. In ways unanticipated during their initial formation, debt displacement has thus become an accumulation strategy in and of itself as an unintended but nevertheless core feature of the AMCs' social content. The AMCs now function at the center of China's strategy to manage ever-new financial risks going bad, within a system of financial capitalism characterized by recurrent crises. The AMCs thus figure as one historically-specific institutional dimension constitutive of a much larger international financial structure.

Our interpretation challenges both mainstream and critical interpretations. For one, mainstream approaches hold fast to neoclassical tenets that, a priori, pose state-owned and public institutions as inherently inefficient. China's AMCs fundamentally undermine propositions that only 'depoliticized' financial institutions can handle bad debts and function effectively. They clearly can handle them effectively, however, this is done more in the private rather than public interest. For another, our interpretation suggests that crises and instabilities can be fixed and resolved - given political capacity to socialize the costs. To be sure, new financial risks and crises arise and can be displaced in time and space, as seen in China. But the concrete foundations of crisis should not be attributed to some original crisis that is then indefinitely displaced via subsequent spatial-temporal maneuvers - with that same initial crisis lurking ever-present ready to rear its head once more. This obscures the exploitative and class-based nature of how state authorities have pushed financial risks gone bad onto society through the state apparatus in ways that disproportionately benefit the reproduction of financial capitalism and private accumulation interests.

It would be a mistake, by way of closing, to draw from our study that only pro-market, procapital social forces can form and reform the social content of state financial institutions (or wider state apparatus) to their benefit. Instead, who shapes and benefits from state institutions is subject to historically specific struggles themselves influenced by structural and conjunctural political economic forces, which cannot be predetermined. If pro-market forces can shape a financial institution (more or less) to a desired end, so too can popular democratic forces. There is nothing guaranteeing a socially progressive end, but then again there is nothing guaranteeing its failure (except the failure to try). Indeed, by theoretically and concretely dismantling the fixed and ahistorical categories of mainstream economic theory a whole world of historically informed empirical research into the potential of financial institutions becomes not only possible, but desirable.

The significance of this insight is urgent. China is mobilizing massive financial resources (some $\$ 900$ billion) towards spatial transformation vis-à-vis regional infrastructure (that is, the Belt and Road Action Plan). So too is China a lead investor in a promised green 
transformation. Who will benefit? Who will define or redefine the social content of these state spatial-temporal strategies? These are questions hardly limited to China but must too be asked of the many powerful and influential state financial institutions around the world. 


\section{Bibliography}

BIS. 2002. Supervisory Guidance on Dealing with Weak Banks. Bank for International Settlements. Available at: http://www.bis.org/publ/bcbs88.pdf.

BIS. 2015. Guidelines for Identifying and Dealing with Weak Banks. Bank for International Settlements. Available at: http://www.bis.org/bcbs/publ/d330.pdf.

Bloomberg. 2013. Bad Banks Turn Toxic China Debt to Treasure for Investors. Available at: http://www.bloomberg.com/news/articles/2013-10-09/bad-banks-turn-toxic-china-debt-totreasure-for-investors.

Bonin, John P. and Huang, Yiping. 2001. "Dealing with the Bad Loans of the Chinese Banks." Journal of Asian Economics 12(2), 197-214.

Bottelier, Pieter. 2009. "The Evolution of Banking and Finance in China: Domestic and International Aspects." In M. Zhu, J. Cai, and M. Avery (eds.), China's Emerging Financial Markets: Challenges and Global Impact. London: John Wiley \& Sons, 53-70.

Breslin, Shaun. 2011. "China and the Crisis: Global Power, Domestic Caution and Local Initiative." Contemporary Politics, 17(2), 185-200.

Caprio, Gerard and Daniela Klingebiel. 2003. Episodes of Systemic and Borderline Financial Crises (Dataset 1). Available at: http://go.worldbank.org/5DYGICS7B0 (Accessed: 20 July 2016).

CBRC. 2004 - 2006. Jinrong Zichanguanligongsi Zichan Chuzhi Qingkuangbiao [Status Report on Asset Disposal by Asset Management Companies]. China Banking Regulatory Commission.

CBRC. 2004 - 2010. Shangyeyinghang Buliangdaikuan Qingkuangbiao [Status Report on Non-Performing Loans of Commercial Banks]. China Banking Regulatory Commission.

CBRC. 2006. Jinrong Zichanguanligongsi Zichan Chuzhi Qingkuangbiao [Status Report on Asset Disposal by Asset Management Companies]. China Banking Regulatory Commission.

CCB (China Construction Bank). 2010. China Construction Bank Corporation Announcement Regarding the Bond of China Cinda Asset Management Corporation. Available at:

http://www.hkexnews.hk/listedco/listconews/sehk/2010/0809/LTN20100809503.pdf.

Cha, Ariana Eunjung and Maureen Fan. 2008 "China Unveils \$586 Billion Stimulus Plan," Washington Post, 10 November, 2008.

Chancellor, Edward. 2011. "China's Bad Debts a Cause for Concern," Financial Times, 10 July 2011. Available at: www.ft.com.

Chen, Weitsang. 2006. "WTO: Time's Up for Chinese Banks - China's Banking Reform and Non-Performing Loan Disposal." Chicago Journal of International Law 7(1), 239-261.

Chen, Yun. 2009. Transition and Development in China: Towards Shared Growth. Farnham, United Kingdom: Ashgate Publishing.

Cheng, Siwei. 2013. Financial Reforms and Developments in China. Singapore: World Scientific Publishing Co. 
Cinda (China Cinda Asset Management Co., Ltd) 2013. Global Offering. (Accessed: 22 August 2016).

Clarke, Simon. 1994. Marx's Theory of Crisis. London: St. Martin's Press.

Cull, Robert and Lixin Colin Xu. 2003. "Who Gets Credit? The Behavior of Bureaucrats and State Banks in Allocating Credit to Chinese State-Owned Enterprises." Journal of Development Economics 71(2), 533-559.

Davies, Paul J. 2012. “China's Cinda Sells \$1.6bn Stake," Financial Times, 16 March 2012. Available at: http://www.ft.com.

Davies, Paul J. 2013. "China Moves Towards Market Remedy for Bad Loans," Financial Times, 15 August 2013. Available at: http://www.ft.com.

Dziobek, Claudia. 1998. "Market-Based Policy Instruments for Systemic Bank Restructuring." IMF Working Paper WP/98/113. Washington, D.C.: International Monetary Fund.

Fewsmith, Joseph. 2001. "The Political and Social Implications of China's Accession to the WTO." The China Quarterly 167, 573-591.

Fortune. 2017. The Fortune 2017 Global 500. Available at: http://fortune.com/global500/ (Accessed: 1 September 2017).

Fung, Ben, Jason George, Stefan Hohl and Guonan Ma. 2004. "Public Asset Management Companies in East Asia - Case studies." Financial Stability Institute Occasional Paper No.3. Basel: Bank for International Settlements.

Great Wall (China Great Wall Asset Management Corporation) (undated) Dashiji [Chronicle of Events]. Available at: http://www.gwamcc.com/Einfo.aspx.

Guo, Shuqing. 2009. "Fundamental Issues and Challenges Facing the Chinese Economy." In M. Zhu, J. Cai, and M. Avery (eds.) China's Emerging Financial Markets: Challenges and Global Impact. Singapore: John Wiley \& Sons Ltd., 3-18.

He, Fei. 2008. "Jinrong Zichanguanligongsi Chixufazhan Cunzaide Wenti Ji Duice." [Issues and Solutions regarding the Continued Development of Financial Asset Management Companies]. Dangdai Jingji [Contemporary Economics] 3(1), 130-131.

Hilferding, Rudolf. 1981 [1910]. Finance Capital: A Study of the Latest Phase of Capitalist Development. Translated from the original 1910 German book by Morris Watnick and Sam Gordon. London: Routledge \& Kegan Paul.

Ho, Prudence. 2013. "China Cinda IPO Raises \$2.5 Billion," The Wall Street Journal, 5 December 2013. Available at: http://www.wsj.com.

Hong, Zhengchong and Jingyu Zhao. 2010. "Qiantan Woguo Guoyouyinhang De Buliang Zichan Chuzhi Moshi" [A Brief Discussion on the Handling of Impaired Assets of StateOwned Banks]. Dongfang Qiye Wenhua [Oriental Corporate Culture], p. 24.

$\mathrm{Hu}$, Jianzhong and Liangjun Xu 2011. "Jinrong Zichanguanligongsi Zhuanxing De DiweiHe Zuoyong." [The Status and Function of the Transformation of Financial Asset Management Companies] Zhongguo Jinrong [China Finance] 15, 74-77. 
Huarong (China Huarong Asset Management Co Ltd). 2015. Global Offering. Available at: http://www.hkexnews.hk.

Jessop, Bob. 2016. "Territory, Politics, Governance and Multispatial Metagovernance." Territory, Politics, Governance 4(1), 8-32.

Jiang, Xueqing. 2016. "China Orient to revamp ahead of eventual IPO," China Daily, 12 January 2016. Available at www.chinadailyasia.com.

Klingebiel, Daniela. 2000. "The Use of Asset Management Companies in the Resolution of Banking Crises - Cross-Country Experience', Policy Research Working Papers. WPS 2284. Washington, D.C.: World Bank.

Konings, Martijn. 2018. Capital and Time: For a New Critique of Neoliberal Reason. Stanford University Press.

Laeven, Luc and Fabian Valencia. 2008. "Systemic Banking Crises: A New Database." IMF Working Paper. WP/08/224. Washington, D.C.: International Monetary Fund.

Lai, Xiaomin. 2010. Speech at '21st Century Asia Finance' 5th Annual Meeting. Available at: http://finance.ifeng.com.

Li, De. 2004. "Woguo Jinrong Zichanguanligongsi Yunying Zhuangkuang Fenxi Ji Weilai Fazhan." [Analysis on Chinese AMCs' Operations and Future Development] Hainan Jingrong [Hainan Finance] 1, 9-11.

Li, Weiling. 2004. "Guowuyuan Pizhun Fangan, Sida Zichanguanligongsi Zhuanxing Fangxiang Chuding." [State Council Approved Proposal Outlined the Direction for Transformation of the Big Four Asset Management Companies] Guoji Jinrong Bao [International Financial Post] 2 March 2004. Available at: http://news.xinhuanet.com.

Liang, Yan. 2010. "China and the Global Financial Crisis: Assessing the Impacts and Policy Responses." China \& World Economy 18(3), 56-72.

Lin, Kun-Chin. 2008. "Macroeconomic Disequilibria and Enterprise Reform: Restructuring the Chinese Oil and Petrochemical Industries in the 1990s." The China Journal 60, 49-79.

Lo, Chi. 2015. China's Impossible Trinity: The Structural Challenges to the "Chinese Dream". London: Palgrave Macmillan.

Ma, Guonan. and Ben S.C. Fung. 2002. "China's Asset Management Corporations." BIS Working Papers. No 115. Basel: Bank for International Settlements.

Marois, Thomas. 2012. States, Banks and Crisis: Emerging Finance Capitalism in Mexico and Turkey. Cheltenham, UK: Edward Elgar Publishing.

Marois, Thomas. 2014. "Historical Precedents, Contemporary Manifestations: Crisis and the Socialization of Financial Risk in Neoliberal Mexico." Review of Radical Political Economics (46)3, 308-330.

Marois, Thomas. and Ali Rıza Güngen. 2016. "Credibility and Class in the Evolution of Public Banks: The Case of Turkey." Journal of Peasant Studies (43)6, 1285-1309. 
Mattlin, Mikael. 2007. "The Chinese Government's New Approach to Ownership and Financial Control of Strategic State-owned Enterprises." Discussion Papers 10/2007. Helsinki: Bank of Finland, BOFIT, Institute for Economies inTransition.

Orient (China Orient Asset Management Corporation) (2014) Chronicle of Events. Available at: http://www.coamc.com/dfzch/dfjsh.

Osuji, Onyeka. 2012. "Asset Management Companies, Non-performing Loans and Systemic Crisis: A Developing Country Perspective." Journal of Banking Regulation 13(2), 147-170.

Overholt, William H. 2010. "China in the Global Financial Crisis: Rising Influence, Rising Challenges." The Washington Quarterly 33(1), 21-34.

Pearson, Margaret M. 2007. "Governing the Chinese Economy: Regulatory Reform in the Service of the State." Public Administration Review 67(4), 718-730.

Qiang, Qu. 2003. "Corporate Governance and State-Owned Shares in China Listed Companies." Journal of Asian Economics 14(5), 771-783.

SETC (State Economic and Trade Commission). 1999. Guanyu Shishi Zhaiquan Zhuan Guquan Ruogan Wenti De Yijian. [Opinion on Certain Questions Concerning Implementing Debt-to-Equity Conversion] No.727.

SETC. 2001. "Zhaizhuangu Shi Shixiang Guoyouqiye Gaige Yu Tuokun Sannian Mubiao De Zhongyao Cuoshi." [Debt-to-equity Conversion is a Key Measure to Achieve 3-year Reform and Resolution of State-owned Enterprises] Zhongguo Jingmaoi Daokan [China Economic and Trade Journal] 15, 9-11.

Shih, Victor. 2004. "Dealing with Non-Performing Loans: Political Constraints and Financial Policies in China." The China Quarterly 180, 922-944.

State Council. 1999a. A Notification regarding the State Council's Forwarding of the 'Opinions Concerning the Establishment of China Huarong Asset Management Company, China Great Wall Asset Management Company, and China Dongfang Asset Management Company'.

State Council. 1999b. Opinions Concerning the Establishment of China Xinda Asset Management Company.

State Council. 2000. Regulation on Financial Asset Management Companies.

Studwell, Joe. 2014. How Asia Works: Success and Failure in the World's Most Dynamic Region. London: Profile Books.

Tang, Fuyong and Feina Zhu. 2003. Zichanguanligongsi Zhuanxing Jichu Yi Jiuxu [The Asset Management Companies are Ready to Transform]. Available at:

http://www.china.com.cn/chinese/FI-c/406298.htm.

Tobin, Damian. 2017. "Is China on the verge of a banking crisis?" The Conversation, 25 April 2017.

Tobin, Damian and Laixiang Sun. 2009. "International Listing as a Means to Mobilize the Benefits of Financial Globalization: Micro-level Evidence from China." World Development 37(4), 825-838. 
Walter, Carl and Fraser Howie. 2012. Red Capitalism: The Fragile Financial Foundation of China's Extraordinary Rise. Singapore: John Wiley \& Sons.

Wang, Junmin, Doug Guthrie and Zhixing Xiao. 2012. "The Rise of SASAC: Asset Management, Ownership Concentration, and Firm Performance in China's Capital Markets." Management and Organization Review 8(02), 253-282.

Wang, Kejing. (2007) "Zhaizhuanggu Xiaoying De Fenxi Pingjia [Analysis and Evaluation of the Effect of Debt-to-Equity Conversion]", in K. Wang (ed.) Zichanguanligongsi: Yunying Zhuangkuang He Weilai Fazhan Fangxiang [Asset Management Companies: Operation Status and Directions for Future Development]. Beijing: China Financial and Economic Publishing House, pp.197-200.

Wang, Tingting and Hui Wu. (2004) 'Sida Zichanguanligongsi Andu Touhang, Shangyehua Zhuanxing Hequhecong [Big Four Asset Management Companies Surreptitiously Switching to Investment Banks; How Are They Doing on Commercial Transformation?]', Diyi Caijing Ribao [First Financial Daily], 23 December 2004. Available at: http://www.people.com.cn/GB/jingji/1040/3074299.html.

Wang, Xingyi. 2002. "Dui Woguo Jinrong Zichanguanligongsi Fazhan De Huigu Yu Sikao." [Reflection and Thoughts on the Development of China's Financial Asset Management Companies] Zhongguo Jinrong [China Finance] 8, 10-13.

Wen, Jiabao. 2010. Zhengfu Gongzuo Baogao [Government Work Report]. Available at: http://www.npc.gov.cn/npc/xinwen/2010-03/15/content_1563942.htm.

Wong, Christine. 2011. "The Fiscal Stimulus Programme and Public Governance Issues in China." OECD Journal on Budgeting 11(3), 1-22.

World Bank. 2010. China Quarterly Update. Washington, D.C.: World Bank.

Xiao, Meng. 1994. 'Xiandai Qiye Zhidu, Yinhang Yu Caizheng De Peitao Gaige - Ji "Zhongguo Jingji Tizhi De Xiayibu Gaige" Guoji Yantaohui.' [Modern Corporate System, Bank and Financial Reform - International Conference on "The Next Step of China's Economic Reform"] Jingji Shehui Tizhi Bijiao [Comparative Economic and Social Systems]6, 25-31.

Ye, Yanfei. 2003. The Way of Dealing with Non-performing Loans and Its Effects on Macrostatistics in China. Washington, D.C.: IMF.

Zhan, Xiangyang. 2000. Lun Zhongguo Buliang Zhaiquan Zhaiwu De Huajie. [On Resolving the Bad Debts in China]. Beijing: Zhongguo Jinrong Chubanshe [China Financial Press].

Zhang, Chenghui. 2004. "Jinrong Zichanguanligongsi De Weilai Fazhan Zouxiang." [Direction for Future Development of the Financial Asset Management Companies] Jinrong Shibao [Financial Times] 18 May 2004. Available at: http://www.drc.gov.cn.

Zhang, Shu and Matthew Miller. 2016. "China Great Wall, seeking IPO, enters "new era" as a joint-stock firm." Reuters, 11 December 2016. Available at: http://www.reuters.com.

Zhang, Xianan. 2016. "Sida AMC Zhuimeng Datouhang: Xinda Huarong Jiezuxiandeng." [The Big Four AMCs Dream of Becoming Investment Banks: Cinda and Huarong are the Quickest to Succeed] Huaxia Shibao [China Times], 8 January 2016. Available at:

http://finance.sina.com.cn. 
Zhao, Suisheng. 2010. "The China Model: Can It Replace the Western Model of Modernization?" Journal of Contemporary China 19(65), 419-436.

Zhou, Xiaochun. 1996. "Guanyu Zhaizhuangu De Jige Wenti." [A Few Questions Concerning Debt-to-Equity Swap] Jingji Shehui Tizhi Bijiao [Comparative Economic and Social Systems] $6,1-9$.

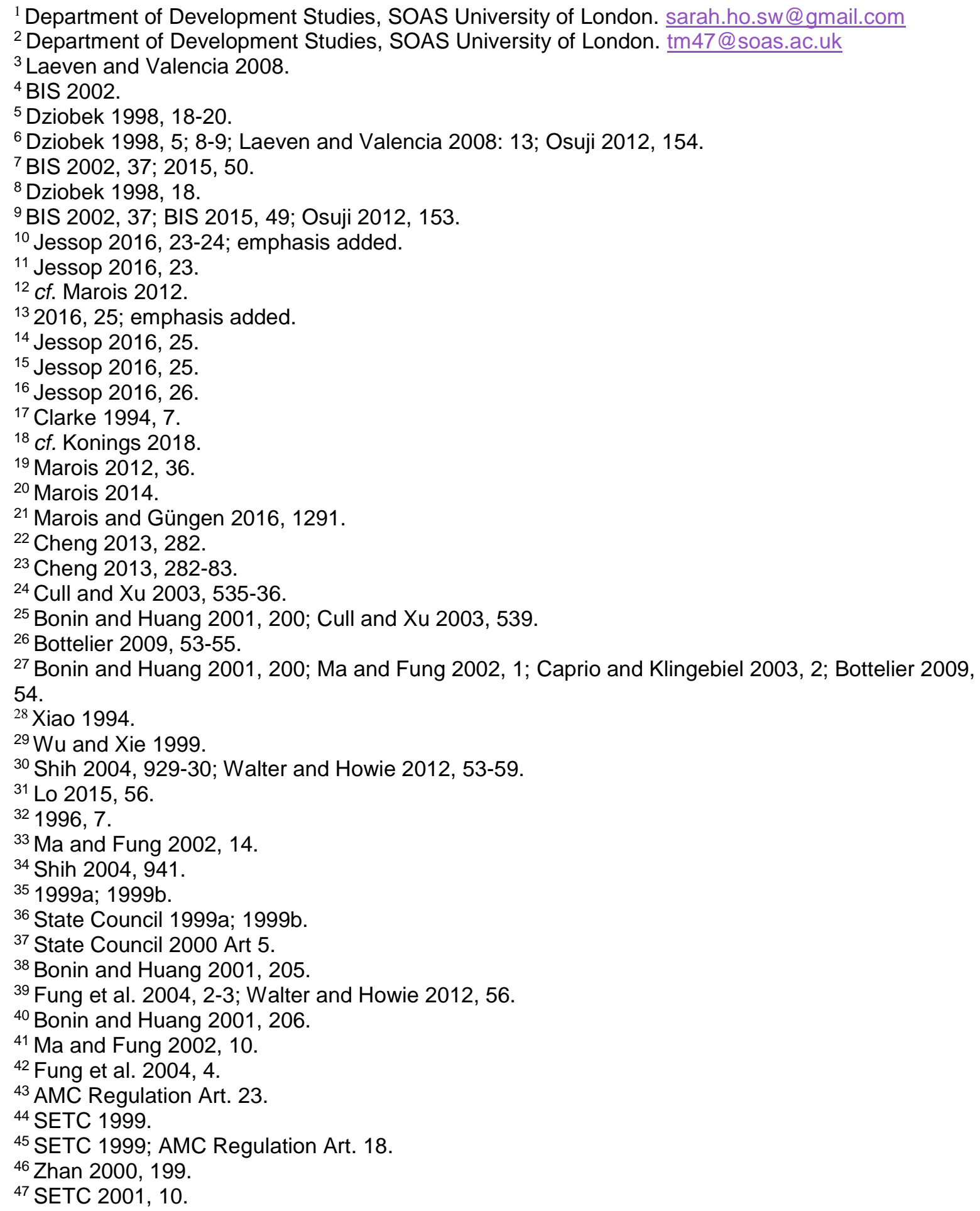




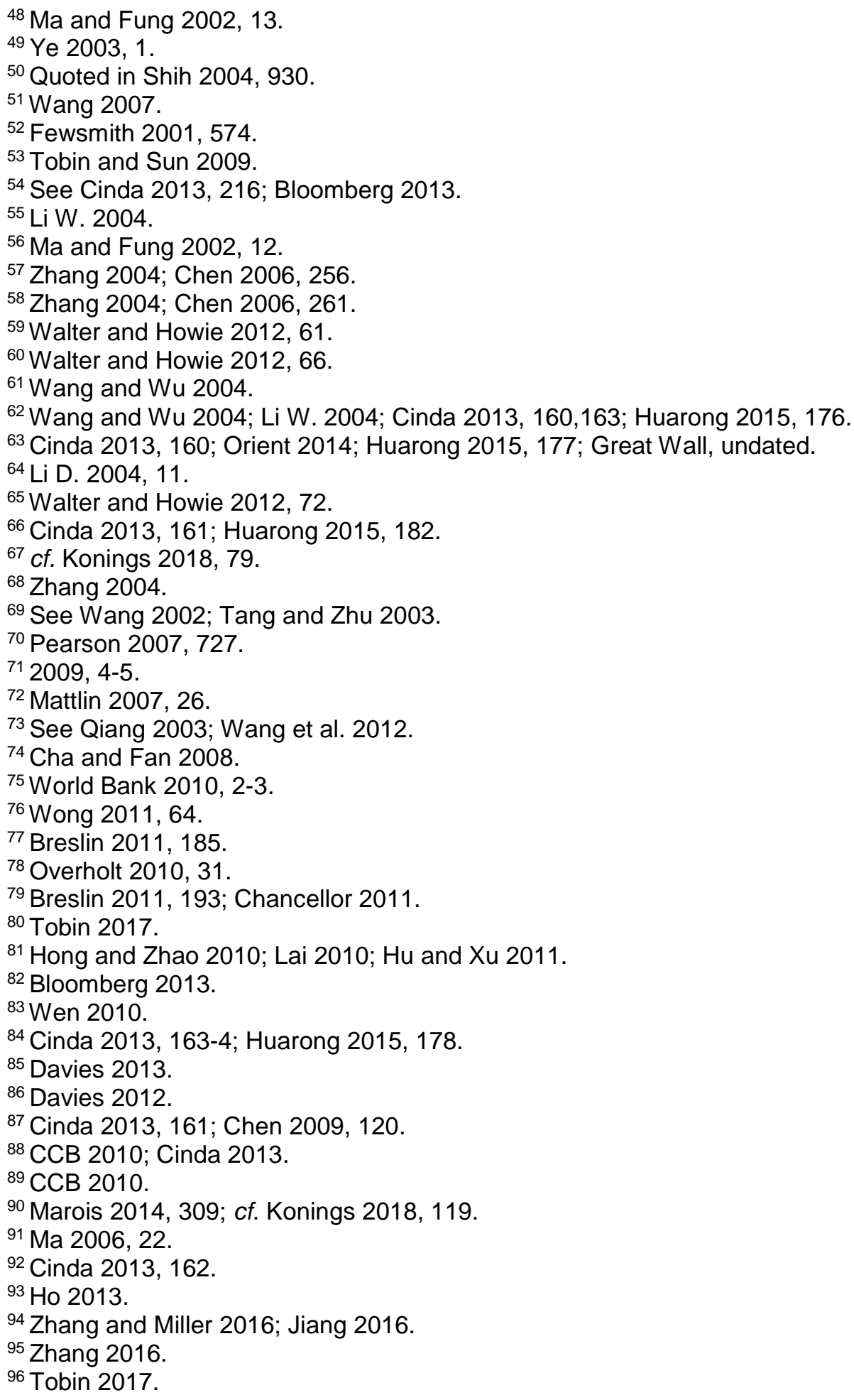

